\title{
TECTONIC CRUSTAL DEFORMATION OF CORINTH GULF, GREECE, BASED ON PRIMARY GEODETIC DATA
}

\section{Ilias LAZOS ${ }^{1)}$ *, Alexandros CHATZIPETROS ${ }^{1)}$, Spyros PAVLIDES ${ }^{1)}$, Christos PIKRIDAS ${ }^{2)}$ and Stylianos BITHARIS ${ }^{2)}$}

\author{
1) School of Geology, Faculty of Sciences, Aristotle University of Thessaloniki, 54124 Thessaloniki, Greece \\ 2) School of Rural and Surveying Engineering, Faculty of Engineering, Aristotle University of Thessaloniki, 54124 Thessaloniki, Greece
}

*Corresponding author's e-mail: iliaslazoseng@yahoo.com

\begin{tabular}{|c|c|}
\hline ARTICLE INFO & ABSTRACT \\
\hline Article history: & \multirow{4}{*}{$\begin{array}{l}\text { The broader Corinth Gulf region is characterized by a notable active tectonic regime, associated } \\
\text { with multiple active fault zones. The continuous N-S extensional tectonics of the area is } \\
\text { responsible for the roughly E-W trending active normal fault zones, while individual fault } \\
\text { segments are associated with seismic events. Satellite geodesy is a qualitative and quantitative } \\
\text { means of estimating the tectonically active setting, based on the recorded motions. The study area } \\
\text { is monitored by } 14 \text { permanent GPS/GNSS stations, collecting primary geodetic data for a 7-year } \\
\text { time period (2008-2014). A 30-sec observation rate was performed, resulting in the extraction of } \\
\text { the GPS/GNSS velocity values. The primary geodetic data were processed by applying the } \\
\text { triangulation methodology, based on the combination of three different GPS/GNSS stations data, } \\
\text { which were considered as the triangle vertices. Triangulation methodology led to the construction } \\
\text { of } 26 \text { different triangles, while for each of them a series of parameters was determined. In } \\
\text { particular, the extracted parameters are: a) Maximum Horizontal Extension, b) Total Velocity, } \\
\text { c) Maximum Shear Strain and d) Area Strain. The extracted results are expected to approach, } \\
\text { qualitatively and quantitatively, the interpretation of the tectonic regime, as well as to determine } \\
\text { new, seismic-related, tectonic features. }\end{array}$} \\
\hline $\begin{array}{l}\text { Received } 15 \text { May } 2020 \\
\text { Accepted } 31 \text { August } 2020 \\
\text { Available online } 7 \text { October } 2020\end{array}$ & \\
\hline Keywords: & \\
\hline $\begin{array}{l}\text { Active tectonics } \\
\text { Triangulation methodology } \\
\text { GPS/GNSS stations } \\
\text { Corinth Gulf } \\
\text { Greece }\end{array}$ & \\
\hline
\end{tabular}

\section{INTRODUCTION}

The Aegean region is tectonically the most active area in the Mediterranean region (Jackson and McKenzie, 1988; Le Pichon et al., 1995; Le Pichon and Angelier, 1981; McKenzie, 1978; Mercier et al., 1977), as its present-day geodynamics is controlled by the $\mathrm{W}-\mathrm{SW}$-ward propagation of the Anatolian plate with a speed of $3-3.5 \mathrm{~cm} / \mathrm{yr}$, as well as the subduction of the African plate beneath the Eurasian one (Hellenic Arc), converging at a rate of approximately $1 \mathrm{~cm} / \mathrm{yr}$ towards the NNE (e.g. Armijo et al., 1996; Hatzfeld, 1994; Hollenstein et al., 2008, 2003; McClusky et al., 2000; Reilinger et al., 2006).

Corinth Gulf is the most active rift within the Aegean region (Fig. 1), showing remarkable tectonic and seismic activity (Jolivet et al., 2013 and references therein; Ring et al., 2010 and references therein), while it is characterized as a complex tectonic structure (length and width of 110 and $30 \mathrm{~km}$, respectively) that generally trends $\mathrm{N} 120^{\circ} \mathrm{E}$. Various interpretations have been proposed for the Corinth Gulf tectonic regime. The prevailing interpretation for the western part indicates the existence of a N-dipping detachment fault, which braches to the surface through steeper normal faults, showing also secondary antithetic structures (e.g. Bernard et al., 1997; Exadaktylos et al., 2003; Flotté et al., 2005; Flotté and Sorel, 2001; Gautier et al., 2006; King et al., 1985; Lyon-Caen et al., 2004;
Rietbrock et al., 1996; Rigo et al., 1996; Sachpazi et al., 2003; Skourtsos and Kranis, 2009; Sorel, 2000). In addition, the asymmetric rift interpretation, based on the domination of the southern faults over the antithetic, northern ones, is supported by various researchers (Cotterill, 2006; Goldsworthy and Jackson, 2001; Jackson et al., 1982; Moretti et al., 2003; Roberts, 1996; Taylor et al., 2011). A similar, more symmetrical structure is proposed by Bell et al. (2008) and McNeill et al. (2005). Ghisetti and Vezzani (2005) defined a differentiation of the western and the eastern part of Corinth Gulf, related to the thickness of the Piocene-Pleistocene faulted deposits (thinner at the western part) and the seismic activity depth (shallower at the western part). This differentiation is due to the crust structure or the presence of a core complex at the western part of the Corinth Gulf (Chéry, 2001; Jolivet et al., 2010).

The extensional activity of the Corinth Gulf has been studied by various researchers (e.g. Collier et al., 1992; Koukouvelas, 1998; Mesimeri and Karakostas, 2018), while $\mathrm{N}-\mathrm{S}$ extension rates of $4-15 \mathrm{~mm} / \mathrm{yr}$ have been estimated, being consistent with the E-W to NWSE trending active fault zones (Armijo et al., 1996; Davies et al., 1997; Maniatis et al., 2003). The prevailing extension rates are concentrated on the detachment fault, either as a result of equilibrium lack between the rift propagation direction and the 


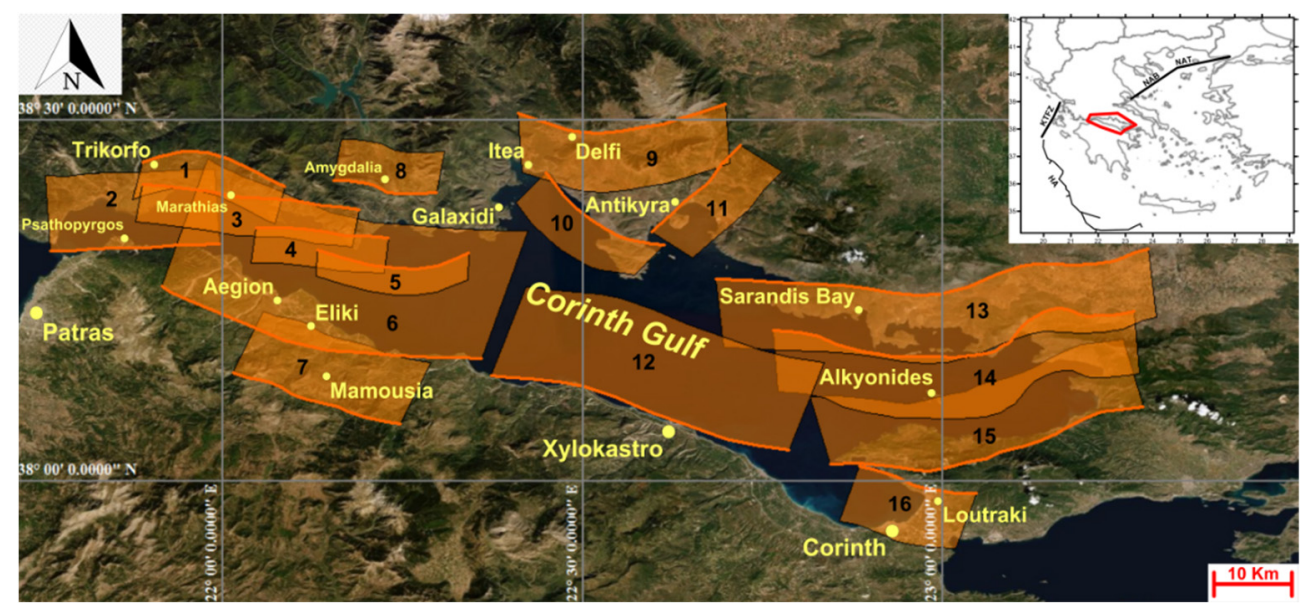

Fig. 1 Location of Corinth Gulf in Greece (red polygon) and the major tectonic-geodynamic features (NAT: North Aegean Trough, NAB: North Aegean Basin, KTFZ: Kefalonia Transform Fault Zone, HA: Hellenic Arc) (inlet) - The Composite Seismogenic Sources of Corinth Gulf (GRCSs - orange boxes), based on the Greek Database of Seismogenic Sources (1: GRCS441: Trikorfo, 2: GRCS442: Marathias, 3: GRCS505: Psathopyrgos, 4: GRCS444, 5: GRCS500: South Corinth Gulf, 6: GRCS500: South Corinth Gulf (Aegion fault, West Heliki fault, East Heliki fault), 7: GRCS524: Mamousia, 8: GRCS436: Kokinovrahos, 9: GRCS430: Delfi, 10: GRCS438: Itea Gulf, 11: GRCS440: Antikyra, 12: GRCS510: Xylokastro, 13: GRCS425: Sarandis Bay, 14: GRCS520: North Alkyonides Gulf, 15: GRCS518: South Alkyonides Gulf, 16: GRCS522: Loutraki) (modified from Caputo et al., 2012; Sboras, 2011; Pavlides et al., 2010).

weakened crust orientation (Rigo et al., 1996; Tiberi et al., 2000), or due to the subduction and trench rollback (Leeder et al., 2003; Sachpazi et al., 2003). In addition, the remarkable crust deformation of the wider Corinth Gulf area is recorded by GPS stations (Avallone et al., 2004; Bernard et al., 2006; Briole et al., 2000; Clarke et al., 1998; Mattei et al., 2004), as well as by seismic analyses (Bernard et al., 2006; Hatzfeld et al., 2000; Jackson et al., 1982; McKenzie, 1978; Tselentis and Makropoulos, 1986). However, differentiation is observed between the eastern and western part of the Corinth Gulf, as the former shows lower extension than the latter. According to the GPS data analysis (Briole et al., 2000), the estimated Corinth Gulf opening of the western part is $1.5 \mathrm{~cm} / \mathrm{yr}$, while at the eastern part is $0.5 \mathrm{~cm} / \mathrm{yr}$. Furthermore, the on land areas of the Corinth Gulf region show uplift, while the central offshore part is characterized by subsidence. In addition, morphological, offshore coastal characteristics, related to steep slopes and deep canyons (Fernández-Blanco et al., 2020; Maniatis et al., 2003) are observed.

Regarding the Corinth Gulf fault zones, the general pattern consists of E-W to NW-SE trending, normal, subparallel and dipping to the north faults at the southern gulf's margin, related to the aforementioned dominant detachment fault, as well as antithetic faults at the northern margin, confirming the rift character of Corinth Gulf (Palyvos et al., 2005; Pavlides et al., 2003; Stefatos et al., 2002; Tsodoulos et al., 2008). According to the Greek Database of Seismogenic Sources (GreDaSS) (Caputo et al., 2012; Sboras, 2011), 16 Composite Seismogenic Sources (CSSs) are identified (Fig. 1), several of which are associated with strong and destructive earthquakes (Ambraseys, 2009; Bernard et al., 1997; Papaioannou and Papazachos, 2000; Papazachos and Papazachou, 2003; Papazachos, 1990).

The aim of this paper is to contribute to the understanding of the crustal deformation multiparametric analysis of the Corinth Gulf region, using primary data, derived from permanent GPS/GNSS stations, in order to examine the tectonic setting on a geodetic basis. The calculation, combination and evaluation of different parameters are expected to contribute in the qualitative and quantitative determination of the tectonic regime, as well as the suggestion of recently reactivated structures.

\section{GPS/GNSS DATA AND PROCESSING}

The GPS/GNSS dataset, analyzed in previous studies (Bitharis, 2015; Bitharis et al., 2016), is exclusively based on a permanent GPS/GNSS network. Within the Corinth Gulf region, the permanent network includes 14 GPS/GNSS stations (Fig. 3), while the recorded velocities are referred to European Terrestrial Reference Frame 2000 (ETRF2000), considering the Eurasian Plate as stable (Lazos et al., 2018a). It should be mentioned that 12 of 14 stations are part of HxGN SmartNet (Network) in Greece, while Metrica SA is responsible for their operation. In addition, the GNSS_QC research team of Auth is responsible for processing monitoring and quality control of Network coordinates, while the other two stations are part of NOANet.

Regarding the GPS/GNSS data processing, it was carried out using GAMIT/GLOBK software (Herring et al., 2015) while the methodology described by Dong et al. (1998) was followed. In particular, at first, the daily raw GPS data were processed, considering a sampling rate of $30 \mathrm{sec}$ in order to estimate station coordinates, zenith 


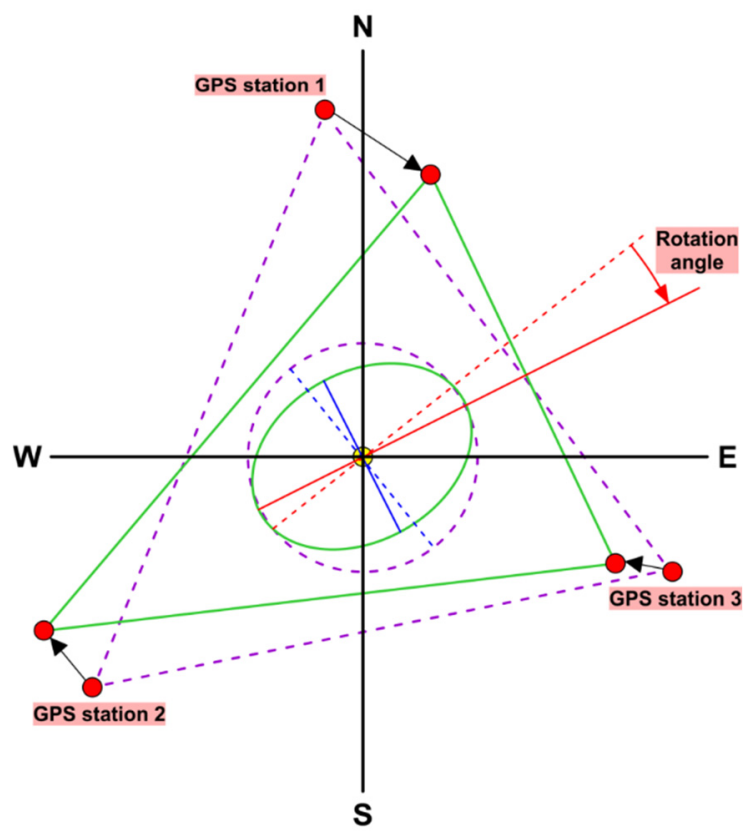

Fig. 2 The undeformed (purple and dashed) and the deformed (green and solid) triangle include the inner circle (purple and dashed) and the ellipse (green and solid), respectively. The triangle centroid (yellow dot) is located at the starting point $(0,0)$ of the coordinate system, as well as in the centre of the circle and the ellipse. The major and the minor axis of the circle (red and blue dashed line, respectively) and the ellipse (red and blue solid line, respectively) are perpendicular to each other, while the triangle centroid is their intersection point. The velocity vectors (black vectors) show the displacement of each GPS station. The angle between the major (or minor) axis of the undeformed triangle and the major (or minor) axis of the deformed triangle constitutes the rotation angle.

atmospheric (tropospheric) delay for each station (with $2 \mathrm{hr}$ interval), orbital and Earth orientation parameters. We applied the recommended necessary corrections and models for the ocean (Lyard et al., 2006) and atmospheric loading tides (Tregoning and van Dam, 2005). For the orbital a-priori information, the IGS precise final orbits were used, while before the site coordinates and velocities estimation, the data from outliers or discontinuities and equipment changes (antenna replacement) were cleared out. Secondly, the loosely constrained daily solutions of site positions, orbit and EOP were applied, to estimate station coordinates and velocities calculated by a Kalman filtering sequential approach.

The set of geodetic velocities is derived from a 7-year (2008-2014) daily GPS/GNSS data processing, using 155 permanent stations, distributed in the broader Greek territory and 30 IGS-EPN GPS/GNSS stations (Bitharis et al., 2016). In most sites the data span exceeds a 4-year period, while the velocities determination standard deviation in the horizontal plane is smaller than $0.8 \mathrm{~mm} / \mathrm{yr}$. It is worth mentioning that in general, horizontal velocity vectors in the Greek area are greater than the corresponding vertical ones, because there are not intense geophysical phenomena with impact in height movements, e.g. postglacial rebound (Bitharis et al., 2017).

\section{METHODOLOGY}

The GPS/GNSS data processing is performed based on GPS stations triangulation methodology (Lazos et al., 2020), taking into account the combination of three different GPS stations. At first, the east and north velocity components for each GPS station are determined, leading to the calculation of total velocity vectors. Subsequently, the three GPS stations are considered as the vertices of a theoretical triangle, assigned to a coordinate system. Then, the three medians are drawn, the intersection of which defines a point, i.e. the triangle centroid. The extracted parameters described below are estimated for the triangle centroid, which is considered as the representation of the entire triangle (Lazos et al., 2018b).

The triangle centroid is then considered as the starting point $(0,0)$ of a newly defined coordinate system, where the two coordinate systems axes (original and new) are parallel to each other. Based on the triangle centroid, an inner circle is inscribed into the original, undeformed triangle, while the total velocity vectors of each GPS station are also drawn.

Taking into account the three total velocity vectors, the translation vector is calculated, representing the average of the aforementioned vectors, while it is drawn on the starting point (triangle centroid) of the coordinate system, in the center of the circle. The triangle vertices relocation, from the starting to the finishing point of each velocity 


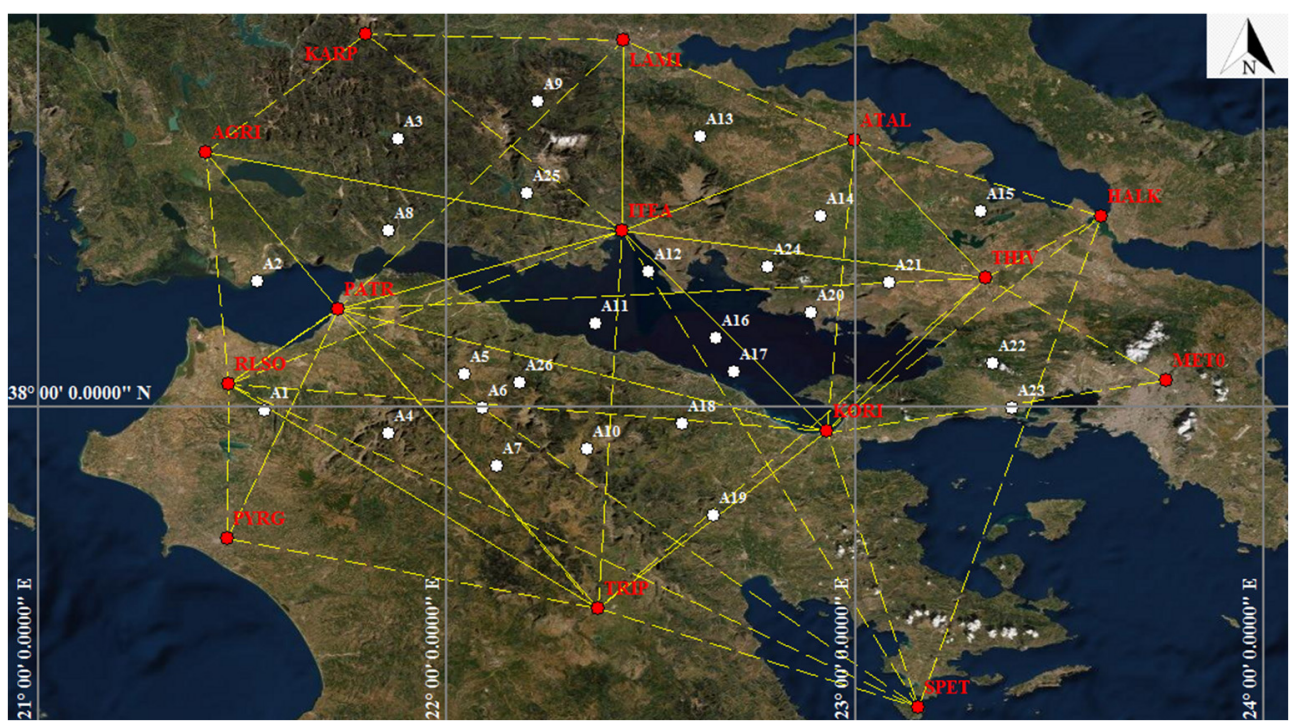

Fig. 3 Distribution map of the 14 permanent GPS/GNSS stations (red dots) of the study area, recording the primary geodetic data, the 26 triangles and the 26 examination points - triangle centroids (white dots), derived from the triangulation methodology implementation.

vector, causes the triangle to deform (Fig. 2). Therefore, the inscribed circle turns into an ellipse, while the undeformed triangle centroid vector maintains its original form after the transformation process (Lazos et al., 2018c).

Following this, each translation vector of the deformed triangle is subtracted, relocating the deformed triangle centroid to the coordinate system starting point $(0,0)$, while the determination of the two triangular centroids identical location is performed. Each site vector affecting the triangle shape and orientation is equivalent to the total site velocity minus the translation vector. The comparison between the undeformed and the deformed triangle shows change of the inscribed circle, as the deformed triangle inner circle is transformed into an ellipse, related to the horizontal strain. The vertices relocation into the positions causes the transformation of the deformed triangle ellipse into a circle, maintaining the strain ellipse major and minor axes perpendicular to each other.

Taking into consideration the fact that the study area is monitored by 14 permanent GPS/GNSS stations, the triangle construction procedure leads to the formation of a large number of potential triangles. For the implementation of the method and the extraction of more reliable results, not all of them were used. The selection of the appropriate triangles used was based on specific criteria, such as the closest location between the combined stations and the normal geometry condition (Lazos et al., 2020). In total, 26 different triangles were constructed (Fig. 3) and the deformation parameters were calculated for each one (Table 1).

Based on the aforementioned process and the application of mathematical equations, consisting of relationships between the lengths (original and final) of the ellipse axes, the calculation of a series of crustal deformation parameters is achieved (more details follow below), i.e.: a) Maximum Horizontal Extension, b) Total Velocity, c) Maximum Shear Strain and d) Area Strain. The implementation of GPS triangulation process is carried out by the 'GPS triangular calculator' software provided by UNAVCO (http://www.unavco.org).

\subsection{MAXIMUM HORIZONTAL EXTENSION}

Maximum Horizontal Extension (MHE) is an important index, revealing tectonic activity, as well as the occurrence of tectonic features within a study area. The MHE is developed perpendicularly to the strike of active normal dip-slip faults. The correlation of MHE with the dominant tectonic setting of an area shows the tectonic activity type (extensional or compressional), related to the normal, reverse or strike-slip structures development. Therefore, the examination of this parameter is expected to highlight the location of each fault type activity. Mathematically, the MHE is estimated (along the major axis of the strain ellipse), implementing the following equation:

$M H E=\left(l_{f}-l_{0}\right) / l_{0}$

where

$l_{f}$ : the final length along the strain ellipse major axe, and

$l_{0}$ : the original lengthalong the strain ellipse major axe.

\subsection{TOTAL VELOCITY}

The Total Velocity (TV) indicator shows the geotectonic evolution of a study area into a specified geotectonic setting. As far as the active motion of the broader Aegean region is concerned (Hollenstein et al., 2008; McClusky et al., 2000; Reilinger et al., 2006), the highest velocity values are recorded near 
the African - Eurasian subduction zone area. The total velocity calculation is based on the north and east velocity components of the triangle centroid, derived from the north and east velocity components combination of the three GPS/GNSS stations, while the highest values is also expected to be located near the aforementioned subduction zone. The values are calculated, performing the Pythagorean Theorem, defined by the equation:

$T V=\sqrt{N^{2}+E^{2}}$

where

$N$ : the north velocity component, and

$E$ : the east velocity component.

\subsection{MAXIMUM SHEAR STRAIN}

The Maximum Shear Strain (MSS) parameter can be used as an indicator of active fault zones, since deformation along fault zones is related to shearing of these structures (Hackl et al., 2009). In particular, shearing, and therefore high MSS values, is mainly related to active normal faults, as well as to active strike-slip faults, as these fault types are fully or partially related to extensional regime. On the other hand, low MSS values are generally recorded in compressional regime regions, where shearing is limited, as ductile and semi-ductile conditions dominate. The MSS is mathematically expressed by the following equation:

$M S S=e_{1 H}-e_{2 H}$

where

$e_{1 H}$ : the extension along the major axis $\left(S_{1 H}\right)$ of the ellipse, and

$e_{2 H}$ : the extension along the minor axis $\left(S_{2 H}\right)$ of the ellipse.

\subsection{AREA STRAIN}

The Area Strain (AS) indicator determines the deformation type, as well as the prevailing tectonic setting of a study area, and it is expressed by two representative types: dilatation and compaction. Dilatation shows an area increase (positive values), related to a dominant extensional setting, in contrast to compaction, which is associated with an area decrease (negative values), indicating the prevalence of a compressional setting. Interpreting in tectonic terms, the dilatation in an area is related to normal dip-slip or transtensional strike-slip faulting, while the compaction indicates an area subjected to reverse dipslip or transpressional strike-slip faulting. High AS values (dilatation) are expected in the close Corinth Gulf area. The AS estimation is performed by applying the following equation:

$A S=e_{1 H}+e_{2 H}$

where

$e_{1 H}$ : the extension along the major axis $\left(S_{1 H}\right)$ of the ellipse, and

$e_{2 H}$ : the extension along the minor axis $\left(S_{2 H}\right)$ of the ellipse.

\section{RESULTS AND DISCUSSION}

\subsection{MAXIMUM HORIZONTAL EXTENSION}

The MHE results reveal the direction of extension, ranging between NNW-SSE and NNE-SSW, represented by vectors, located perpendicularly to the E-W Corinth Gulf fault zones strike (Fig. 4a). However, regional differentiations between the MHE vectors are observed, due to the differentiated fault segments strike, composing the Corinth Gulf fault zones.

Based on the calculation of 26 different MHE values, a geostatistical approach was applied, implementing an interpolation (kriging) methodology (Fig. 4b), leading to distribution of the MHE values in a grid pattern. The calculated values range between 14.91 and 341.47 nano-strain (Table 1), indicating an area of considerable tectonic activity. The highest MHE values are observed within the offshore Corinth Gulf area (especially its western and central part), highlighting the fault zones activity, while they are gradually decreasing when moving away perpendicularly to the gulf.

\subsection{TOTAL VELOCITY}

Initially, it should be mentioned the fact that the estimated velocity of each centroid, leading to the initial velocity "replacement" of the three vertices (GPS stations), results in the extraction of dense examination points and therefore the more accurate velocity calculation of an area.

The calculated TV vectors (Fig. 5a) show a NE-SW deformation of the Corinth Gulf area, consistent with the general NE-SW Aegean motion, considering the Eurasian plate as a fixed reference frame (ETRF2000), while the corresponding values range between 15.16 and $30.11 \mathrm{~mm} / \mathrm{yr}$ (Table 1). The geostatistically-based results (Fig. 5b) show that the lowest values are observed at the northernnortheastern part of the study area, while the crust is deformed with highest velocity values extend towards its southern part. It is generally deduced that the TV values increase, as the distance to the Hellenic Arc reduces.

\subsection{MAXIMUM SHEAR STRAIN}

The calculated MSS values (Fig. 6a) range between 32.84 and 402.60 nano-strain (Table 1), confirming the tectonically active character of the Corinth Gulf area. In general, a gradual decrease of the MSS values is observed, as the distance from the Corinth Gulf area increases. The lowest MSS values are concentrated at the eastern and the southern part of the study area, while the highest ones are observed within the offshore Corinth Gulf part and towards the NW part of mainland Peloponnese. These latter values (mainly $A_{1}$ and $A_{2}$ examination points) are not consistent with the general active tectonics pattern, while additionally they are not strictly associated with the Corinth Gulf tectonic regime. The high MSS values of the W-SW Corinth Gulf region are associated to the seismic event of $8^{\text {th }}$ June 2008 


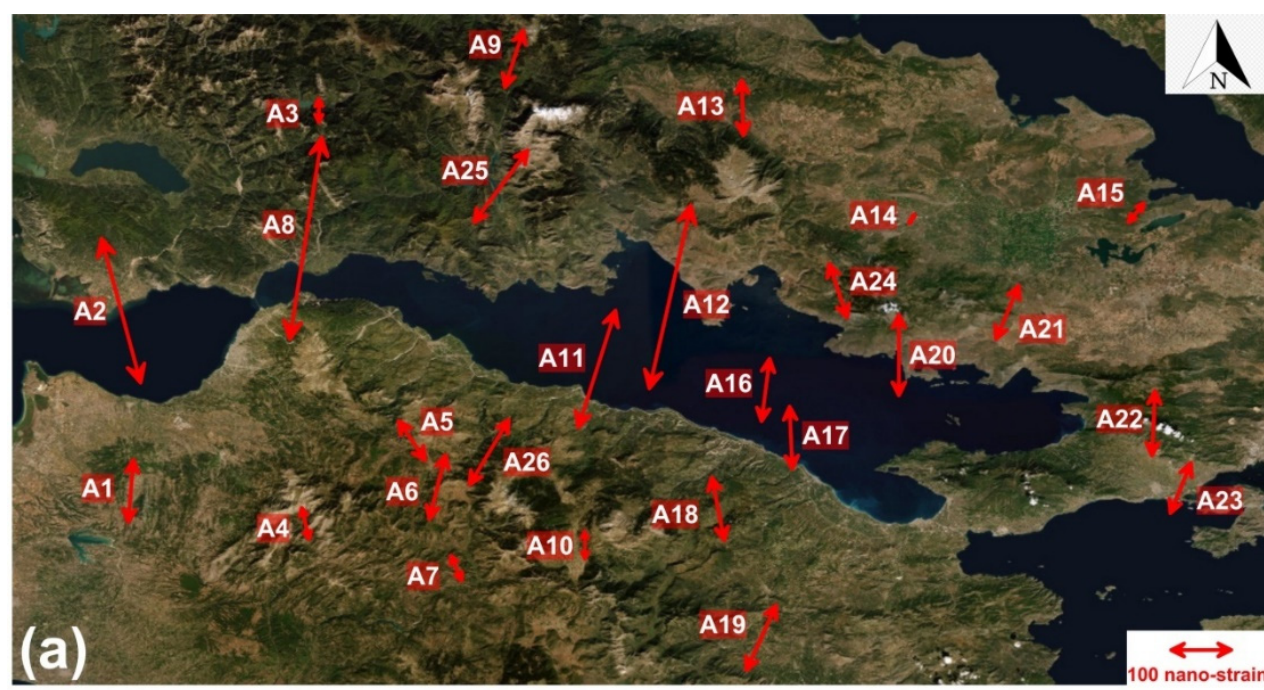

(a)

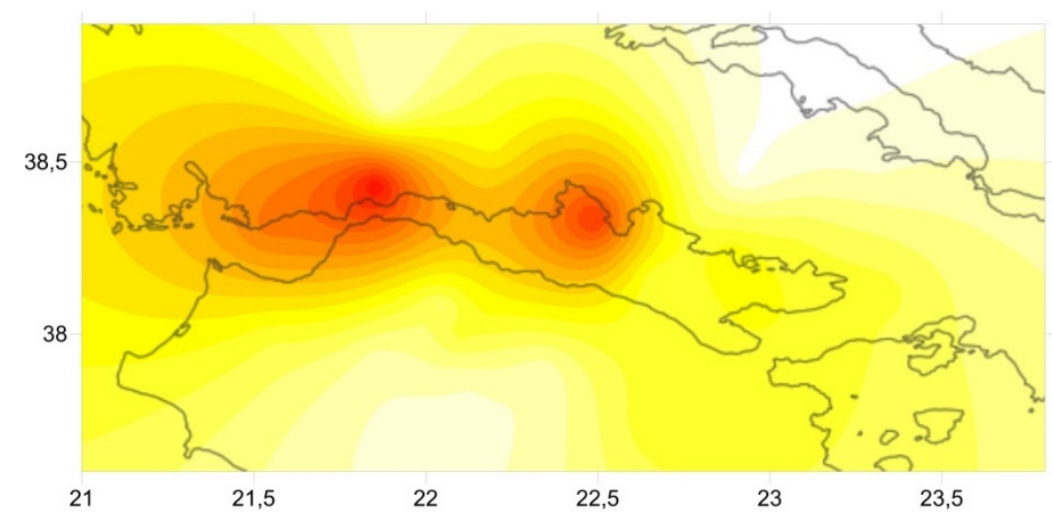

(b)

Fig. 4 (a) The MHE values (red vectors) map of the study area, showing the distribution of highest values within Corinth Gulf, while lower values are present in the broader area, (b) Interpolation map of MHE values, showing their gradual decrease, as the distance from the Corinth Gulf area itself increases.

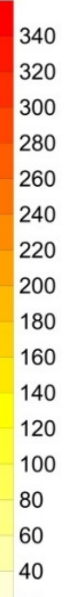

320
300
280
260
240
220
200
180
160
140
120
100
80
60
40
20

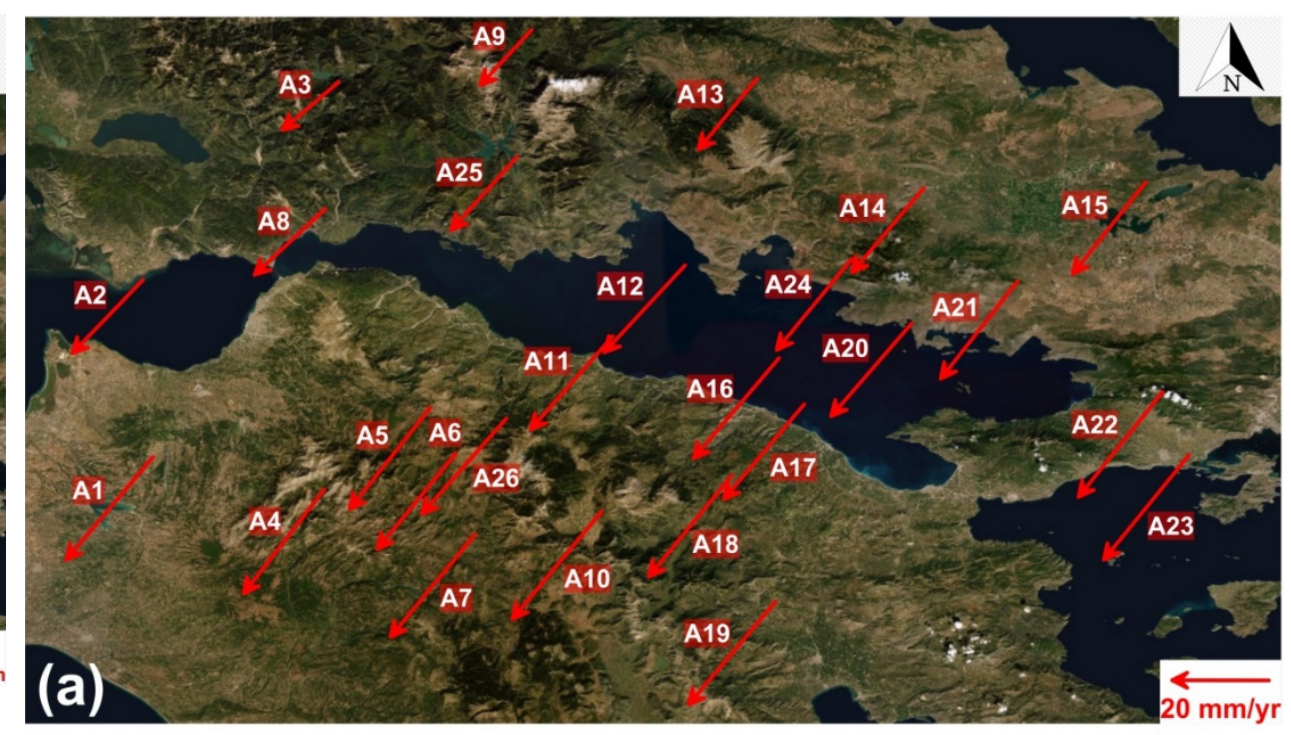

(b)

Fig. 5 (a) The TV values (red vectors) map of the study area, showing the predominant motion towards the SW. The value of TV increases towards the South, (b) Interpolated TV distribution map, showing a pattern of gradual increase towards the South. 
$\left(\mathrm{M}_{\mathrm{w}}=6.4\right)$ in NW Peloponnese area (e.g. Koukouvelas et al., 2010), recorded by the GPS/GNSS stations (the recording time period is $2008-2014$, as mentioned above), leading to the triggering of tectonic structures, imprinted in the primary geodetic data. The interpolated MSS values (Fig. 6b) confirm the presence of the highest values within the Corinth Gulf offshore part, while the shearing impact dominates the western-southwestern, meisoseismal region. From a seismotectonic point of view, this interpretation shows that the seismic-caused shearing is likely to have triggered and activated adjacent tectonic structures.

\subsection{AREA STRAIN}

The AS analysis (Fig. 7a) implies extended positive values ( $85 \%$ of the examination points) throughout the study area, revealing dilatation of the Corinth Gulf region and therefore a prevailing extensional regime, represented by the broad normal faulting occurrence. The highest dilatation values are located within the offshore Corinth Gulf area, in accordance with the MHE values. On the contrary, the negative AS strain values, concentrated in the western-southwestern part of the study area, are limited (15\% of the examination points) and associated with a limited compaction of this region. This compaction indicates transpressional strike-slip faulting, excluding reverse faulting, based on the knowledge of the local seismotectonic setting. In particular, the identified reverse faults in the area are considered inactive (old alpine tectonics), as they do not affect Neogene sediments. This is also supported by seismological data and studies. Strike-slip type of faulting is well supported by the June $8^{\text {th }} 2008$ seismic event, as the seismological data and fault plane solutions reveal the activity of a transpressional, strike-slip fault (e.g. Koukouvelas et al., 2010; Margaris et al., 2010; Serpetsidaki et al., 2010). The geostatistical processing of AS values (Fig. 7b), ranging between -137.73 and 334.29 nano-strain, shows a gradual reduction of the positive values, as the distance from Corinth Gulf area increases while the coexistence of the interpolated, grid-patterned, positive and negative AS values is an additional indication of transpressional strike-slip faulting. In addition, the transpressional strike-slip faulting effect is confirmed by the existence of a "buffer zone" (white colored zone), surrounded on both sides by positive and negative values.

\section{CONCLUSIONS}

The contribution of satellite geodesy is decisive for the tectonic regime - geotectonic evolution determination and interpretation of a large- or smallscale region. Our study area is Corinth Gulf, one of the tectonically most active regimes globally, monitored by 14 permanent GPS/GNSS, recording primary geodetic data, applying ETRF2000 as a reference frame. The collected data, including the East and
North velocity component of each GPS/GNSS station, as well as the corresponding errors, are processed by the triangulation methodology implementation. This methodology is based on a triangle construction, locating three GPS/GNSS stations on the triangle vertices, while the combined geodetic data of these stations lead to the extraction of four parameters (Maximum Horizontal Extension, Total Velocity, Maximum Shear Strain and Area Strain), considered representative for each triangle. The overall defined 26 triangles, expressed by triangle centroids (examination points), are smoothly distributed throughout the study area, while the detailed analysis reveals information about the tectonic evolution and highlights important active tectonic structures, being the scope of the present paper.

As far as the results are concerned, the following concluding remarks can be addressed:

1. The Maximum Horizontal Extension (MHE) vectors show a roughly $\mathrm{N}-\mathrm{S}$ direction, ranging locally from NW-SE to NE-SW, compatible with the general E-W strike of mapped fault zones, as well as the NE-SW and NW-SE trending fault segments, respectively. In addition, the highest MHE values within the Corinth Gulf area confirm the high activity of the Corinth Gulf fault zones. The impact of the fault zones decreases (reduction is concluded by the lower MHE values), as the distance from the strict Corinth Gulf area increases.

2. A general NE - SW motion of the Corinth Gulf region, after considering Eurasian Plate as fixed reference frame, is suggested by the calculated Total Velocity (TV) vectors, being consistent with the motion of the broader Aegean region. A gradual decrease is observed from the northern to the southern part of the study area, justified by shorter distance from the Hellenic Arc, which is the fastest deformed structure in the eastern Mediterranean region.

3. Maximum Shear Strain (MSS) is an indicator related to the active and seismic fault zones activity. Besides the expected high MSS values, located mainly in the offshore Corinth Gulf region, a quite remarkable MSS impact is observed in the western-southwestern part of the study area, being inconsistent with the general MSS pattern. These high MSS values are associated with the seismic event of June $8^{\text {th }} 2008$, which caused shearing of the area.

4. The Area Strain (AS) parameter is indicative of the general dilatation or compaction of the study area, associated with extensional tectonics and therefore the active deformation along normal faults, while the AS values decrease as the distance from the Corinth Gulf fault zones increases. In the westernsouthwestern part of the study area, limited compaction is observed, which can be associated to compressional tectonics and expressed by reverse or transpressional strike-slip faulting. 


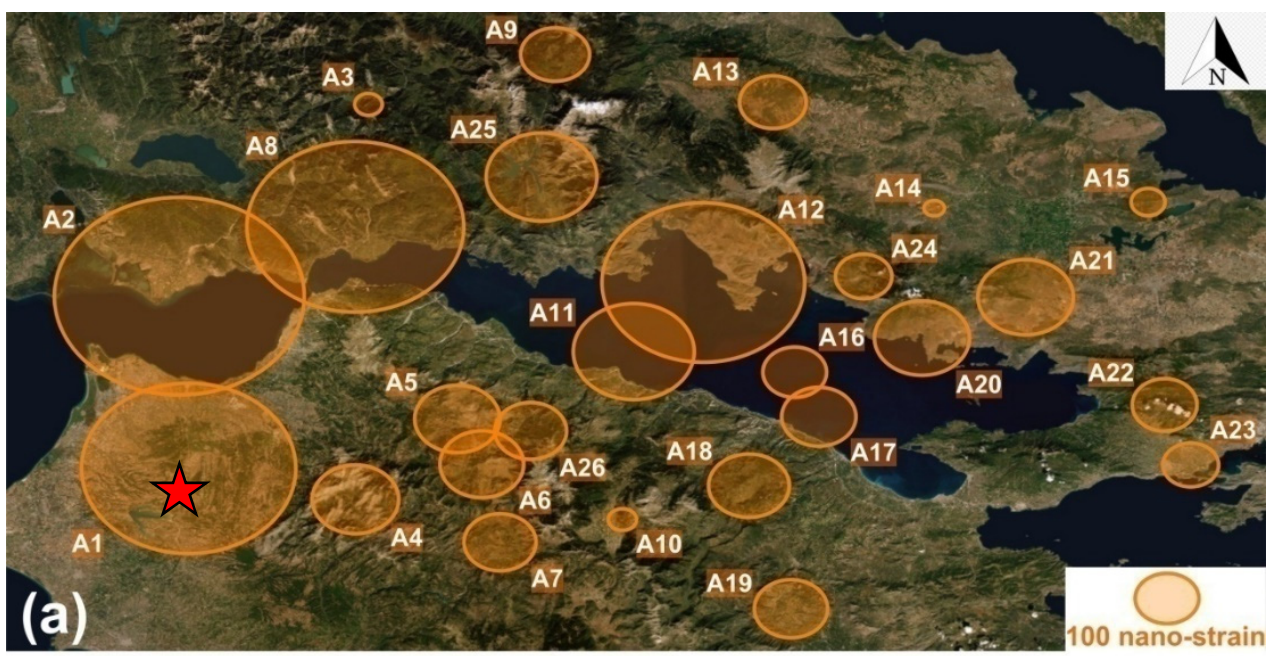

(a)

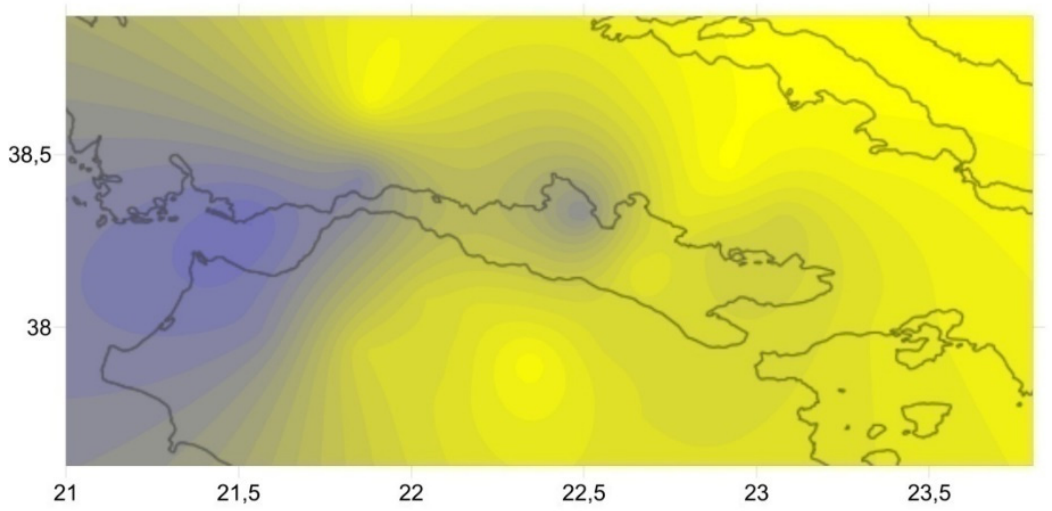

(b)

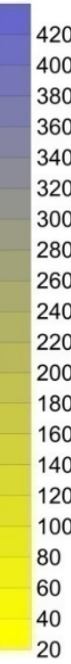

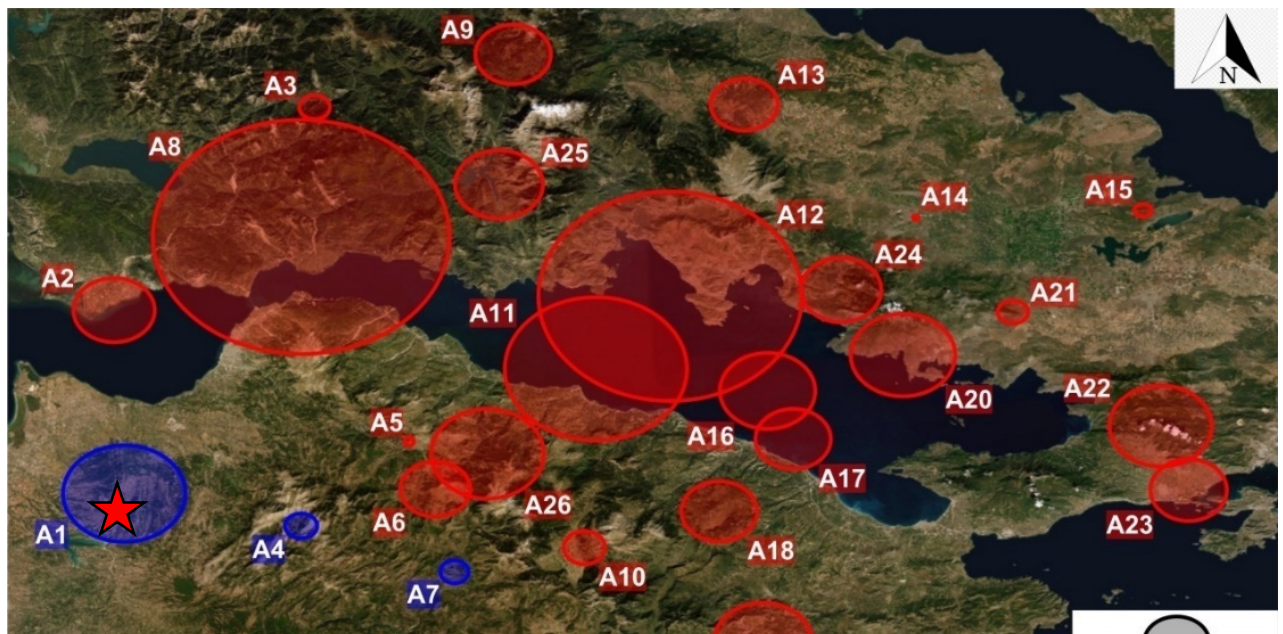

(a)

A19

100 nano-strain

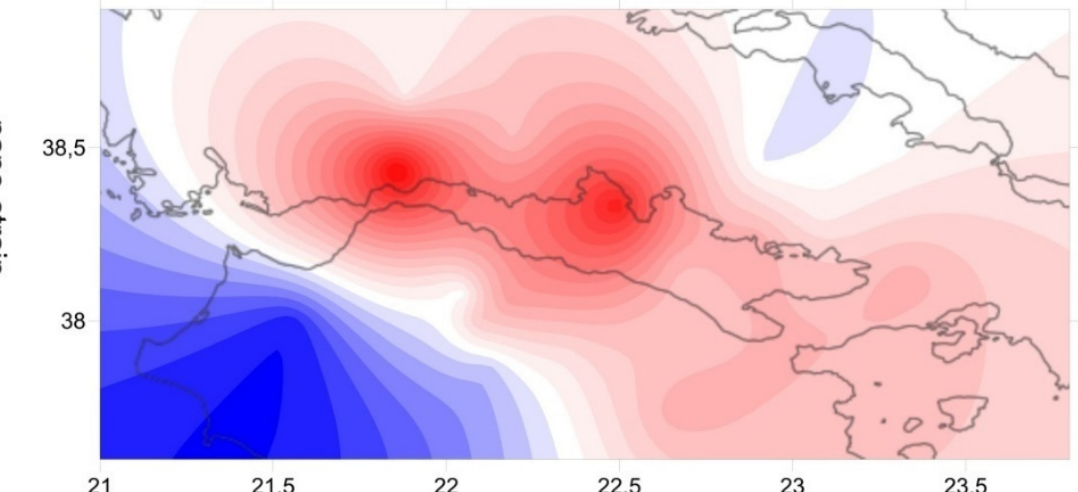

(b)

Fig. 7 (a) The AS values (red ellipses: positive values - dilatation, blue ellipses: negative values - compaction) map of the study area, showing the prevailing dilatation which is associated with the general extensional regime of the area (red star: epicentre of the June $8^{\text {th }} 2008$ seismic event). (b) Interpolated distribution map of AS values, showing that the highest positive values are located within the Corinth Gulf, where the main normal faults of the area are mapped, while the negative values are present at the western-southwestern part, indicating the presence of an active, transpressional, strike-slip fault. 
Table 1 Cumulative parameters results, calculated for each examination point.

\begin{tabular}{rrrrrrr}
\hline $\begin{array}{c}\text { Examination } \\
\text { point }\end{array}$ & Longitude & Latitude & $\begin{array}{c}\text { Maximum } \\
\text { extension } \\
\text { (nano-strain) }\end{array}$ & $\begin{array}{c}\text { Total } \\
\text { velocity } \\
\text { (mm/yr) }\end{array}$ & $\begin{array}{r}\text { Maximum } \\
\text { shear strain } \\
\text { (nano-strain) }\end{array}$ & $\begin{array}{c}\text { Area strain } \\
\text { (nano-strain) }\end{array}$ \\
\hline A1 & 21.552983 & 37.991895 & 104.78 & 28.68 & 347.30 & -137.73 \\
A2 & 21.535729 & 38.306982 & 247.17 & 21.68 & 402.60 & 91.75 \\
A3 & 21.881314 & 38.656359 & 39.73 & 15.16 & 45.31 & 34.14 \\
A4 & 21.857059 & 37.935545 & 52.22 & 28.52 & 140.40 & -35.97 \\
A5 & 22.043640 & 38.081131 & 74.55 & 28.01 & 138.46 & 10.65 \\
A6 & 22.088216 & 37.999155 & 107.23 & 26.57 & 135.88 & 78.58 \\
A7 & 22.121714 & 37.856973 & 42.52 & 28.54 & 117.21 & -32.18 \\
A8 & 21.857691 & 38.432708 & 341.47 & 20.24 & 348.66 & 334.29 \\
A9 & 22.222252 & 38.747381 & 97.37 & 15.90 & 110.22 & 84.52 \\
A10 & 22.345322 & 37.897864 & 46.52 & 30.11 & 45.40 & 47.65 \\
A11 & 22.365435 & 38.205480 & 200.55 & 26.46 & 195.42 & 205.67 \\
A12 & 22.493192 & 38.331143 & 312.15 & 25.07 & 326.46 & 297.85 \\
A13 & 22.620613 & 38.661050 & 90.74 & 19.56 & 107.05 & 74.43 \\
A14 & 22.915648 & 38.467315 & 14.91 & 23.60 & 32.84 & -3.02 \\
A15 & 23.306556 & 38.478487 & 36.93 & 25.27 & 55.87 & 17.99 \\
A16 & 22.660479 & 38.168144 & 105.66 & 28.20 & 103.77 & 107.54 \\
A17 & 22.704420 & 38.085940 & 103.50 & 26.77 & 121.42 & 85.58 \\
A18 & 22.576739 & 37.960509 & 107.80 & 28.17 & 130.35 & 85.25 \\
A19 & 22.653071 & 37.736022 & 114.67 & 28.71 & 119.14 & 110.20 \\
A20 & 22.893014 & 38.230138 & 135.17 & 26.26 & 152.73 & 117.61 \\
A21 & 23.082264 & 38.303743 & 93.66 & 26.75 & 154.01 & 33.31 \\
A22 & 23.336541 & 38.108174 & 110.88 & 29.06 & 105.76 & 116.00 \\
A23 & 23.384614 & 37.997707 & 88.19 & 29.29 & 89.76 & 86.62 \\
A24 & 22.786920 & 38.342138 & 91.08 & 25.00 & 91.58 & 90.59 \\
A25 & 22.197537 & 38.523828 & 138.49 & 21.03 & 179.38 & 97.59 \\
A26 & 22.177908 & 38.060423 & 121.65 & 26.97 & 116.23 & 127.07 \\
\hline
\end{tabular}

Since the reverse faulting of the study area is inactive, it is proposed that the regional compaction is caused by transpressional strike-slip faulting. Seismological data and fault plane solutions of the June $8^{\text {th }} 2008$ earthquake are in agreement with this interpretation.

5. The combination of the three parameters (Maximum Horizontal Extension, Maximum Shear Strain and Area Strain) suggest a uniform tectonic setting of the Corinth Gulf area, characterized by dominant extension, expressed by the remarkably high values of each parameter. At the same time the transpressional, strike-slip tectonic regime is documented at the southwestern part of the study area (northwestern Peloponnese), related to the recent seismic event of June $8^{\text {th }} 2008$. The forth parameter (Total Velocity), indicating the geotectonic evolution of an area, shows the NE-SW motion of the Corinth Gulf region, being consistent with the general NE-SW motion of the entire Aegean region towards the African Eurasian subduction zone area.

\section{ACKNOWLEDGEMENTS}

The authors would like to thank Professor Despina Kondopoulou for the comments and the proposed improvements of the text. Furthermore, authors thank the NOANET (www.gein.noa.gr) and HxGN/SmartNet (www.metricanet.gr) providers for the GPS/GNSS data. On behalf of all authors, the corresponding author states that there is no conflict of interest.

\section{REFERENCES}

Ambraseys, N.: 2009, Earthquakes in the Mediterranean and Middle East: A multidisciplinary study of seismicity up to 1900. Cambridge University Press. DOI: $10.1017 / \mathrm{CBO} 9781139195430$

Armijo, R., Meyer, B., King, G.C.P., Rigo, A. and Papanastaaiou, D.: 1996, Quaternary evolution of the Corinth Rift and its implications for the Late Cenozoic evolution of the Aegean. Geophys. J. Int., 126, 11-53. DOI: 10.1111/j.1365-246X.1996.tb05264.x

Avallone, A., Briole, P., Agatza-Balodimou, A.M., Billiris, H., Charade, O., Mitsakaki, C., Nercessian, A., Papazissi, K., Paradissis, D. and Veis, G.: 2004, Analysis of eleven years of deformation measured by GPS in the Corinth Rift Laboratory area. Comptes Rendus Geosci. 336, 301-311. DOI: $10.1016 /$ j.crte.2003.12.007

Bell, R.E., McNeill, L.C., Bull, J.M., Henstock, T.J.: 2008, Evolution of the offshore western Gulf of Corinth. Bull. Geol. Soc. Am., 120, 156-178. DOI: $10.1130 / \mathrm{B} 26212.1$ 
Bernard, P., Briole, P., Meyer, B., Gomez, J., Tiberi, C., Berge, C., Cattin, R., Hatzfeld, D., Lachet, C., Lebrun, B., Deschamps, A., Courboulex, F., Larroque, C., Rigo, A., Massonnet, D., Papadimitriou, P., Kassaras, J., Diagourtas, D., Makropoulos, K., Veis, G., Papazisi, E., Mitsakaki, C., Karakostas, V and Papadimitriou, E.: 1997, The Ms=6.2, June 15, 1995 Aigion earthquake (Greece): evidence for low-angle normal faulting in the Corinth rift. J. Seismol., 1, 131150. DOI: $10.1023 / \mathrm{A}: 1009795618839$

Bernard, P., Lyon-Caen, H., Briole, P., Deschamps, A., Boudin, F., Makropoulos, K., Papadimitriou, P., Lemeille, F., Patau, G., Billiris, H., Paradissis, D., Papazissi, K., Castarède, H., Charade, O., Nercessian, A., Avallone, A., Pacchiani, F., Zahradnik, J., Sacks, S. and Linde, A.: 2006, Seismicity, deformation and seismic hazard in the western rift of Corinth: New insights from the Corinth Rift Laboratory (CRL). Tectonophysics, 426, 7-30.

DOI: $10.1016 /$ j.tecto.2006.02.012

Bitharis, S.: 2015, Process of GPS permanent stations data and estimation of velocity field in Greek area. Thesis. Aristotle University of Thessaloniki, (in Greek).

Bitharis, S., Ampatzidis, D., Pikridas, C., Fotiou, A., Rossikopoulos, D. and Schuh, H.: 2017, The role of GNSS vertical velocities to correct estimates of sea level rise from tide gauge measurements in Greece. Mar. Geod., 40, 297-314.

DOI: $10.1080 / 01490419.2017 .1322646$

Bitharis, S., Fotiou, A., Pikridas, C. and Rossikopoulos, D.: 2016, A new velocity field of Greece based on seven years (2008-2014) continuously operating GPS station data. IAG Symposia, 147, Cham, 321-329. DOI: 10.1007/1345_2016_230

Briole, P., Rigo, A., Lyon-Caen, H., Ruegg, J.C., Papazissi, K., Mitsakaki, C., Balodimou, A., Veis, G., Hatzfeld, D. and Deschamps, A.: 2000, Active deformation of the Corinth rift, Greece: Results from repeated Global Positioning System surveys between 1990 and 1995. J. Geophys. Res., Solid Earth, 105, 25605-25625. DOI:10.1029/2000JB900148

Caputo, R., Chatzipetros, A., Pavlides, S. and Sboras, S.: 2012, The Greek database of seismogenic sources (GreDaSS): state-of-the-art for northern Greece. Ann. Geophys., 55, 859-894. DOI: 10.4401/ag-5168

Chéry, J.: 2001, Core complex mechnics: From the Gulf of Corinth to the Snake Range. Geology, 29, 439. DOI: 10.1130/0091-7613(2001)029

Clarke, P.J., Davies, R.R., England, P.C., Parsons, B., Billiris, H., Paradissis, D., Veis, G., Cross, P.A., Denys, P.H., Ashkenazi, V., Bingley, R., Kahle, H.G., Muller, M.V. and Briole, P.: 1998, Crustal strain in Greece from repeated GPS measurements in the interval 1989-1997. Geophys. J. Int. 135, 195-214. DOI: 10.1046/j.1365-246X.1998.00633.x

Collier, R.E.L., Leeder, M.R., Rowe, P.J., Atkinson, T.C.: 1992, Rates of tectonic uplift in the Corinth and Megara Basins, central Greece. Tectonics, 11, 11591167. DOI: $10.1029 / 92 \mathrm{TC} 01565$

Cotterill, C.: 2006, A high-resolution Holocene fault activity history of the Aigion Shelf, Gulf of Corinth, Greece. Ph.D Thesis. University of Southampton.

Davies, R., England, P., Parsons, B., Billiris, H., Paradissis, D. and Veis, G.: 1997, Geodetic strain of Greece in the interval 1892-1992. J. Geophys. Res., 102, B11, 24571-24588 DOI: 10.1029/97JB01644
Dong, D., Herring, T.A. and King, R.W.: 1998, Estimating regional deformation from a combination of space and terrestrial geodetic data. J. Geod., 72, 200-214. DOI: $10.1007 / \mathrm{s} 001900050161$

Exadaktylos, G.E., Vardoulakis, I., Stavropoulou, M.C. and Tsombos, P.: 2003, Analogue and numerical modeling of normal fault patterns produced due to slip along a detachment zone. Tectonophysics, 376, 117-134. DOI: $10.1016 /$ j.tecto.2003.08.005

Fernández-Blanco, D., de Gelder, G., Lacassin, R. and Armijo, R.: 2020, Geometry of flexural uplift by continental rifting in Corinth, Greece. Tectonics, 39, DOI: $10.1029 / 2019$ TC005685

Flotté, N. and Sorel, D.: 2001, Structural cross sections through the Corinth-Patras detachment fault-system in Northern Peloponnesus (Aegean Arc, Greece). Bull. Geol. Soc. Greece, 34, 235-241. DOI: 10.12681/bgsg.17018

Flotté, N., Sorel, D., Müller, C. and Tensi, J.: 2005, Along strike changes in the structural evolution over a brittle detachment fault: Example of the Pleistocene CorinthPatras rift (Greece). Tectonophysics, 403, 77-94. DOI: $10.1016 / j$.tecto.2005.03.015

Gautier, S., Latorre, D., Virieux, J., Deschamps, A., Skarpelos, C., Sotiriou, A., Serpetsidaki, A. and Tselentis, A.: 2006, A new passive tomography of the Aigion area (Gulf of Corinth, Greece) from the 2002 data set. Pure Appl. Geophys., 163, 431-453. DOI: $10.1007 / \mathrm{s} 00024-005-0033-7$

Ghisetti, F. and Vezzani, L.: 2005, Inherited structural controls on normal fault architecture in the Gulf of Corinth (Greece). Tectonics, 24, 1-17. DOI: 10.1029/2004TC001696

Goldsworthy, M. and Jackson, J.: 2001, Migration of activity within normal fault systems: Examples from the Quaternary of mainland Greece. J. Struct. Geol., 23, 489-506. DOI: 10.1016/S0191-8141(00)00121-8

Hackl, M., Malservisi, R. and Wdowinski, S.: 2009, Strain rate patterns from dense GPS networks. Nat. Hazards Earth Syst. Sci., 9, 1177-1187. DOI: $10.5194 /$ nhess-9-1177-2009

Hatzfeld, D.: 1994, On the shape of the subducting slab beneath the Peloponnese, Greece. Geophys. Res. Lett., 21, 173-176. DOI: 10.1029/93GL03079

Hatzfeld, D., Karakostas, V., Ziazia, M., Kassaras, I., Papadimitriou, E., Makropoulos, K., Voulgaris, N., Papaioannou, C., 2000. Microseismicity and faulting geometry in the Gulf of Corinth (Greece). Geophys. J. Int., $141,438-456$.

DOI: $10.1046 / j .1365-246 X .2000 .00092 . x$

Herring, T.A., King, R.W., Floyd, M.A. and McClusky, S.C.: 2015, GAMIT Reference Manual. GPS Analysis at MIT.

Hollenstein, C., Kahle, H.G., Geiger, A., Jenny, S., Goes, S., Giardini, D.: 2003, New GPS constraints on the Africa-Eurasia plate boundary zone in southern Italy. Geophys. Res. Lett., 30. 18. DOI: $10.1029 / 2003$ GL017554

Hollenstein, C., Müller, M.D., Geiger, A. and Kahle, H.G.: 2008, Crustal motion and deformation in Greece from a decade of GPS measurements, 1993-2003. Tectonophysics, 449, 17-40. DOI: $10.1016 /$ j.tecto.2007.12.006

Jackson, J. and McKenzie, D.: 1988, Rates of active deformation in the Aegean Sea and surrounding regions. Basin Res., 1, 121-128. DOI: $10.1111 / \mathrm{j} .1365-2117.1988 . t b 00009 . x$ 
Jackson, J.A., Gagnepain, J., Houseman, G., King, G.C.P., Papadimitriou, P., Soufleris, C. and Virieux, J.: 1982, Seismicity, normal faulting, and the geomorphological development of the Gulf of Corinth (Greece): the Corinth earthquakes of February and March 1981. Earth Planet. Sci. Lett., 57, 377-397. DOI: $10.1016 / 0012-821 X(82) 90158-3$

Jackson, J. A., King, G. and Vita-Finzi, C.: 1982, The neotectonics of the Aegean: an alternative view. Earth Planet. Sci. Lett., 61, 303-318. DOI: $10.1016 / 0012-821 \mathrm{X}(82) 90062-0$

Jolivet, L., Faccenna, C., Huet, B., Labrousse, L., Le Pourhiet, L., Lacombe, O., Lecomte, E., Burov, E., Denèle, Y., Brun, J.P., Philippon, M., Paul, A., Salaün, G., Karabulut, H., Piromallo, C., Monié, P., Gueydan, F., Okay, A.I., Oberhänsli, R., Pourteau, A., Augier, R., Gadenne, L. and Driussi, O.: 2013, Aegean tectonics: Strain localisation, slab tearing and trench retreat. Tectonophysics, 597-598, 1-33. DOI: $10.1016 /$ j.tecto.2012.06.011

Jolivet, L., Labrousse, L., Agard, P., Lacombe, O., Bailly, V., Lecomte, E., Mouthereau, F. and Mehl, C.: 2010, Rifting and shallow-dipping detachments, clues from the Corinth Rift and the Aegean. Tectonophysics, 483, 287-304. DOI: 10.1016/j.tecto.2009.11.001

King, G.C.P., Ouyang, Z.X., Papadimitriou, P., Deschamps, A., Gagnepain, J., Houseman, G., Jackson, J.A., Soufleris, C. and Virieux, J.: 1985, The evolution of the Gulf of Corinth (Greece): an aftershock study of the 1981 earthquakes. Geophys. J. Int., 80, 677-693. DOI: $10.1111 / j .1365-246 X .1985 . t b 05118 . x$

Koukouvelas, I.K.: 1998, The Egion Fault, earthquakerelated and long-term deformation, Gulf of Corinth, Greece. J. Geodyn., 26, 501-513. DOI: 10.1016/S0264-3707(97)00046-X

Koukouvelas, I.K., Kokkalas, S. and Xypolias, P.: 2010, Surface deformation during the Mw 6.4 (8 June 2008) Movri Mountain earthquake in the Peloponnese, and its implications for the seismotectonics of western Greece. Int. Geol. Rev., 52, 249-268.

DOI: $10.1080 / 00206810802674329$

Lazos, I., Chatzipetros, A., Pavlides, S., Bitharis, S. and Pikridas, C.: 2018a, Tectonics of the Corinth Gulf, Greece, based on primary geodetic data. Proc. 2nd Scientific Meeting of the Tectonics Committee of the Geological Society of Greece, Patra, 13 June 2018, 24-25.

Lazos, I., Kondopoulou, D., Chatzipetros, A., Pavlides, S., Bitharis, S. and Pikridas, C.: 2018b, Rotation rates of the South Aegean region, Greece, based on primary geodetic data - Comparison between geodetic and palaeomagnetic results. Proc. 9th International INQUA Meeting on Paleoseismology, Active Tectonics and Archeoseismology, Possidi, 25-27 June, 141-144.

Lazos, I., Pikridas, C., Chatzipetros, A. and Pavlides, S.: 2020, Determination of local active tectonics regime in central and northern Greece, using primary geodetic data. Appl. Geomat., 1-15. DOI: $10.1007 / \mathrm{s} 12518-020-00310-\mathrm{x}$

Lazos, I., Stergiou, C.L., Chatzipetros, A., Pikridas, C., Bitharis, S. and Melfos, V.: 2018c, Active tectonics (extensional regime and rotations) and Tertiary mineralization occurrences within Central Macedonia, Greece. Proc. 9th International INQUA Meeting on Paleoseismology, Active Tectonics and Archeoseismology, Possidi, 25-27, 145-148.
Le Pichon, X. and Angelier, J.: 1981, The Aegean Sea. Philos. Trans. R. Soc. London, Ser. A, 300, 357-372.

Le Pichon, X., Chamot-Rooke, N., Lallemant, S., Noomen, R. and Veis, G.: 1995, Geodetic determination of the kinematics of central Greece with respect to Europe Implications for Eastern Mediterranean tectonics. J. Geophys. Res., Solid Earth, 100, 12675-12690. DOI: 10.1029/95JB00317

Leeder, M.R., McNeill, L.C., Collier, R.E.LI., Portman, C., Rowe, P.J., Andrews, J.E. and Gawthorpe, R.L.: 2003, Corinth rift margin uplift: New evidence from Late Quaternary marine shorelines. Geophys. Res. Lett., 30, 1611. DOI: $10.1029 / 2003$ GL017382

Lyard, F., Lefevre, F., Letellier, T. and Francis, O.: 2006, Modelling the global ocean tides: Modern insights from FES2004. Ocean Dyn., 56, 394-415. DOI: $10.1007 / \mathrm{s} 10236-006-0086-\mathrm{x}$

Lyon-Caen, H., Papadimitriou, P., Deschamps, A., Bernard, P., Makropoulos, K., Pacchiani, F. and Patau, G.: 2004, First results of the CRLN seismic network in the western Corinth Rift: Evidence for old-fault reactivation. Comptes Rendus - Geosci., 336, 343351. DOI: 10.1016/j.crte.2003.12.004

Maniatis, G., Lempp, C. and Heinisch, H.: 2003, 3D strain monitoring of onshore active faults at the eastern end of the Gulf of Corinth (Greece). J. Geodyn., 36, 95102. DOI: $10.1016 / \mathrm{S} 0264-3707(03) 00041-3$

Margaris, B., Athanasopoulos, G., Mylonakis, G., Papaioannou, C., Klimis, N., Theodulidis, N., Savvaidis, A., Efthymiadou, V. and Stewart, J.P.: 2010, The 8 June 2008 Mw6.5 Achaia-Elia, Greece Earthquake: Source characteristics, ground motions, and ground failure. Earthq. Spectra, 26, 399-424. DOI: $10.1193 / 1.3353626$

Mattei, M., D’Agostino, N., Zananiri, I., Kondopoulou, D., Pavlides, S. and Spatharas, V.: 2004, Tectonic evolution of fault-bounded continental blocks: Comparison of paleomagnetic and GPS data in the Corinth and Megara basins (Greece). J. Geophys. Res., Solid Earth, 109. DOI: 10.1029/2003JB002506

McClusky, S., Balassanian, S., Barka, A., Demir, C., Ergintav, S., Georgiev, I., Gurkan, O., Hamburger, M., Hurst, K., Kahle, H., Kastens, K., Kekelidze, G., King, R., Kotzev, V., Lenk, O., Mahmoud, S., Mishin, A., Nadariya, M., Ouzounis, A., Paradissis, D., Peter, Y., Prilepin, M., Reilinger, R., Sanli, I., Seeger, H., Tealeb, A., Toksöz, M.N. and Veis, G.: 2000, Global Positioning System constraints on plate kinematics and dynamics in the eastern Mediterranean and Caucasus. J. Geophys. Res., 105, B3, 5695-5719. DOI: $10.1029 / 1999 J B 900351$

McKenzie, D.: 1978, Active tectonics of the AlpineHimalayan belt: the Aegean Sea and surrounding regions. Geophys. J. R. Astron. Soc., 55, 217-254. DOI: 10.1111/j.1365-246X.1978.tb04759.x

McNeill, L.C., Cotterill, C.J., Henstock, T.J., Bull, J.M., Stefatos, T.J., Collier, R.E.L., Papatheoderou, G., Ferentinos, G. and Hicks, S.E.: 2005, Active faulting within the offshore western Gulf of Corinth, Greece: Implications for models of continental rift deformation. Geology, 33, 241-244. DOI: $10.1130 / \mathrm{G} 21127.1$

Mercier, J.L., Carey, E., Philip, H. and Sorel, D.: 1977, La neotectonique plioquaternaire de l'Arc Egen externe et de la mer Ege et ses relations avec la sismicite. Bull. Soc. Geol. Fr., 18, 159-176. 
Mesimeri, M. and Karakostas, V.: 2018, Repeating earthquakes in western Corinth Gulf (Greece): implications for aseismic slip near locked faults. Geophys. J. Int., 215, 659-676.

DOI: $10.1093 / \mathrm{gji} / \mathrm{ggy} 301$

Moretti, I., Sakellariou, D., Lykousis, V. and Micarelli, L.: 2003, The Gulf of Corinth: An active half graben? J. Geodyn., 36, 323-340. DOI: $10.1016 / \mathrm{S} 0264-3707(03) 00053-\mathrm{X}$

Palyvos, N., Pantosti, D., De Martini, P.M., Lemeille, F., Sorel, D. and Pavlopoulos, K.: 2005, The Aigion-Neos Erineos coastal normal fault system (western Corinth Gulf Rift, Greece): Geomorphological signature, recent earthquake history, and evolution. J. Geophys. Res., Solid Earth, 110, 1-15. DOI: 10.1029/2004JB003165

Papaioannou, C.A. and Papazachos, B.C.: 2000, Timeindependent and time-dependent seismic hazard in Greece based on seismogenic sources. Bull. Seismol. Soc. Am., 90, 22-33. DOI: 10.1785/0119980023

Papazachos, B. and Papazachou, C.: 2003, The earthquakes of Greece. 3rd Edition. Ziti Publications, Thessaloniki, Greece. 286 pp.

Papazachos, B.C.: 1990, Seismicity of the Aegean and surrounding area. Tectonophysics, 178, 287-308. DOI: 10.1016/0040-1951(90)90155-2

Pavlides, S., Caputo, R., Sboras, S., Chatzipetros, A., Papathanasiou, G. and Valkaniotis, S.: 2010, The Greek catalogue of active faults and database of seismogenic sources. Bull. Geol. Soc. Greece, 43, 486-494. DOI: 10.12681/bgsg.11199

Pavlides, S.B., Koukouvelas, I.K., Kokkalas, S., Stamatopoulos, L., Keramydas, D and Tsodoulos, I.: 2003, Late Holocene evolution of the East Eliki fault, Gulf of Corinth (Central Greece). Quat. Int., 115-116, 139-154. DOI: 10.1016/S1040-6182(03)00103-4

Reilinger, R., McClusky, S., Vernant, P., Lawrence, S., Ergintav, S., Cakmak, R., Ozener, H., Kadirov, F., Guliev, I., Stepanyan, R., Nadariya, M., Hahubia, G., Mahmoud, S., Sakr, K., ArRajehi, A., Paradissis, D., Al-Aydrus, A., Prilepin, M., Guseva, T., Evren, E., Dmitrotsa, A., Filikov, S. V., Gomez, F., Al-Ghazzi, R. and Karam, G.: 2006, GPS constraints on continental deformation in the Africa-Arabia-Eurasia continental collision zone and implications for the dynamics of plate interactions. J. Geophys. Res., Solid Earth, 111, B5, B05411. DOI: 10.1029/2005JB004051

Rietbrock, A., Tiberi, C., Scherbaum, F. and Lyon-caen, H.: 1996, Seismic slip on a low angle normal fault in the Gulf of Corinth: Evidence from high-resolution cluster analysis of microearthquakes. Geophys. Res. Lett., 23, 1817-1820. DOI: 10.1029/96GL01257

Rigo, A., Lyon-Caen, H., Armijo, R., Deschamps, A., Hatzfeld, D., Makropoulos, K., Papadimitriou, P. and Kassaras, I.: 1996, A microseismic study in the western part of the Gulf of Corinth (Greece): implications for large-scale normal faulting mechanisms. Geophys. J. Int., 126, 663-688. DOI: $10.1111 / j .1365-246 X . t b 04697 . x$

Ring, U., Glodny, J., Will, T. and Thomson, S.: 2010, The Hellenic subduction system: High-pressure metamorphism, exhumation, normal faulting, and large-scale extension. Annu. Rev. Earth Planet. Sci., $38,45-76$.

DOI: 10.1146/annurev.earth.050708.170910
Roberts, G.P.: 1996, Noncharacteristic normal faulting surface ruptures from the Gulf of Corinth, Greece. J. Geophys. Res., Solid Earth, 101, 25255-25267. DOI: $10.1029 / 96 j b 02119$

Sachpazi, M., Clément, C., Laigle, M., Hirn, A. and Roussos, N.: 2003, Rift structure, evolution, and earthquakes in the Gulf of Corinth, from reflection seismic images. Earth Planet. Sci. Lett., 216, 243-257. DOI: $10.1016 / \mathrm{S} 0012-821 \mathrm{X}(03) 00503-\mathrm{X}$

Sboras, S.: 2011, The Greek database of seismogenic sources: seismotectonic implications for North Greece. University of Ferrara.

Serpetsidaki, A., Sokos, E., Tselentis, G.A. and Zahradnik, J.: 2010, Seismic sequence near Zakynthos Island, Greece, April 2006: Identification of the activated fault plane. Tectonophysics, 480, 23-32. DOI: $10.1016 /$ j.tecto.2009.09.024

Skourtsos, E. and Kranis, H.: 2009, Structure and evolution of the western Corinth rift, through new field data from the northern Peloponnesus. Geol. Soc. Spec. Publ., 321, 119-138. DOI: 10.1144/SP321.6

Sorel, D.: 2000, A Pleistocene and still-active detachment fault and the origin of the Corinth-Patras rift, Greece. Geology, 28, 83-86. DOI: 10.1130/0091-7613

Stefatos, A., Papatheodorou, G., Ferentinos, G., Leeder, M. and Collier, R.: 2002, Seismic reflection imaging of active offshore faults in the Gulf of Corinth: Their seismotectonic signifcance. Basin Res., 14, 487-502. DOI: $10.1046 / \mathrm{j} .1365-2117.2002 .00176 . x$

Taylor, B., Weiss, J.R., Goodliffe, A.M., Sachpazi, M., Laigle, M. and Hirn, A.: 2011, The structures, stratigraphy and evolution of the Gulf of Corinth rift, Greece. Geophys. J. Int., 185, 1189-1219. DOI: 10.1111/j.1365-246X.2011.05014.x

Tiberi, C., Lyon-Caen, H., Hatzfeld, D., Achauer, U., Karagianni, E., Kiratzi, A., Louvari, E., Panagiotopoulos, D., Kassaras, I., Kaviris, G., Makropoulos, K. and Papadimitriou, P.: 2000, Crustal and upper mantle structure beneath the Corinth rift (Greece) from a teleseismic tomography study. J. Geophys. Res., 105, B12, 28159-28171. DOI: $10.1029 / 2000 J B 900216$

Tregoning, P. and van Dam, T.: 2005, Atmospheric pressure loading corrections applied to GPS data at the observation level. Geophys. Res. Lett., 32, L22310. DOI: $10.1029 / 2005$ GL024104

Tselentis, G.A. and Makropoulos, K.C.: 1986, Rates of crustal deformation in the Gulf of Corinth (central Greece) as determined from seismicity. Tectonophysics, 124, 55-66. DOI: 10.1016/0040-1951(86)90137-X

Tsodoulos, I.M., Koukouvelas, I.K. and Pavlides, S.: 2008, Tectonic geomorphology of the easternmost extension of the Gulf of Corinth (Beotia, Central Greece). Tectonophysics, 453, 211-232. DOI: $10.1016 /$ j.tecto.2007.06.015 